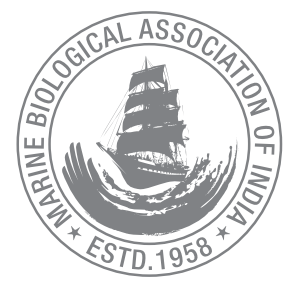

\title{
Bioremediation of industrial effluent at source using aquatic macrophytes
}

\author{
Vani B. Mahesh, Reeta Jayasankar* and Anuja Madhavan \\ ICAR-Central Marine Fisheries Research Institute, Cochin-682 018, Kerala, India. \\ *Correspondence e-mail: reetajayasankar@yahoo.com
}

Received: 25 April 2020 Accepted: 28 Dec 2020 Published: 30 Dec 2020

Original Article

\begin{abstract}
Kerala State in India has $4.3 \%$ of the total number of small-scale industries in the country which is around 4,52,826 and this number is increasing per annum. Even though industrialization and urbanization are considered as the steppingstone to a country's development, the effluents released into the water bodies may lead to unrepairable damage to the aquatic environment thereby affecting livelihood of coastal people. The present investigation was done in Cochin inshore waters (9 $9^{\circ} 59^{\prime} 12.56^{\prime \prime} \mathrm{N}$ and $76^{\circ} 16^{\prime} 20.74^{\prime \prime}$ E) polluted due to effluent discharge into the canal water connecting to the sea through the lake. The chemical parameters showed wide variation in ammonia content in effluent water which was found to be very high with a value of $4.05 \mathrm{mg} / \mathrm{l}$ compared to the normal estuarine water $(0.14 \mathrm{mg} / \mathrm{l})$ and was $96 \%$ higher in effluent water. Similarly, the phosphate and silicate content of the effluent water was about 84.3 and $87.6 \%$ higher than the normal estuarine water. The presence of heavy metals like zinc as well as copper was also observed in the effluent. Experiment conducted in the laboratory using aquatic plants like Eichhornia crassipes, Pistia stratiotes and mangrove such as Rhizophora mucronata and Bruguiera gymnorrhiza for 5 days showed increase in DO and BOD level with decreasing TSS and nutrients. The absorption of ammonium ion was quite low, ranging from $4.0-10.5 \%$, but toxicity of ammonia was observed to affect the aquatic plant and mangrove used for treatment. The biosorption study was carried out for the removal of
\end{abstract}

heavy metals from the effluent by passing through a column packed with seaweed powder of Sargassum wightti and Kappaphycus alvarezii. Sargassum could accumulate zinc $17.6(\mathrm{mg} / \mathrm{kg})$ and copper $(1.96 \mathrm{mg} / \mathrm{kg}$ ) whereas Kappaphycus could accumulate $76.1(\mathrm{mg} / \mathrm{kg})$ of zinc and $16.64(\mathrm{mg} / \mathrm{kg})$ of copper in different effluent collected from outfall area leaving the elute below the detection level. The main aim of this study is to bring forth a new concept of eco-friendly processes to counter contamination of water bodies by phytoremediation using various aquatic plants and suggest the industries to implement this cost effective technology of effluent treatment. This will ensure reuse of freshwater and protect the fragile aquatic system from pollution besides mining the heavy metals from the seaweed through phytomining.

Keywords: Bioremediation, phyto mining, aquatic weeds, mangroves, heavy metals

\section{Introduction}

Human progress paved the way for different innovations in scientific and technological areas. Global development, 
however, raises new challenges, especially in the field of environmental protection and conservation (Bennett et al., 2003). Though the Water Act of India, 1974 provides for the prevention and control of water pollution and maintaining or restoring of wholesomeness of water through various management guidelines and restrictions, ironically, economic, agricultural and industrial developments are often linked to environment pollution (Ikhuoria and Okieimen, 2000). Kerala has a landmass of $1.18 \%$ with a total area of nearly $38,863 \mathrm{~km}^{2}$ and a coastline of $580 \mathrm{~km}, 44$ rivers and 27 backwater bodies which covers $4720 \mathrm{~km}$ of the total land area. Of the 14 districts in Kerala, 9 districts have coastline and population density range from 604 to 1492/ $\mathrm{km}^{2}$ (Coastal Kerala Development Council) which is much higher than the National average. According to the Government of India report under Ministry of Micro, Small, Medium Enterprises (MSME, 20 ${ }^{\text {th }}$ March 2020) Kerala has 4,52,826 small scale industries which is $4.3 \%$ of the country's total SSI. Ernakulam is the most densely populated and this district contributes the State's highest GDP from construction, manufacturing, ship building, seafood, spices, health services, agro based, chemical, fertilizer industries and tourism. Kochi backwater is directly connected to sea through canal, creeks and lake. Eloor, is the industrial belt in Ernakulam District having more than 280 industries situated in the vicinity of backwater and around 110 are chemical industries (Anjusha et al., 2020). Even though there are stringent guidelines by the Central Pollution Control Board for industries (effluent treatment plant in every industry and zero discharge to natural environment), at certain discharge point violation of such guidelines has been observed in the creek and canal waters leading to occasional change in colour of water and also fish mortality. Industrial pollution has contributed to water quality deterioration by the discharge of untreated or partially treated effluent from factories or industries in the district (Sumangala et al., 2013). Physico-chemical parameters like $\mathrm{pH}$, temperature, phenolphthalein alkalinity, acidity, free $\mathrm{CO} 2$, chloride, hardness, phosphate, dissolved oxygen, BOD, COD and total alkalinity were analysed from the Mangalavanam mangrove ecosystem caused due to industrial pollution (Madhusudhanan and Jayesh, 2011). Many of the industries such as paint, textile industries use large amount of zinc oxide for manufacturing purposes (Moezzi et al., 2012). It has been reported that water bodies in the region are biologically polluted with the presence of $\mathrm{Cr}, \mathrm{Mn}$, $\mathrm{Co}, \mathrm{Ni}, \mathrm{Cu}, \mathrm{Zn}, \mathrm{Cd}, \mathrm{Pb}, \mathrm{Bi}, \mathrm{As}, \mathrm{Hg}$ (Sobha and Anish, 2003). Several conventional methods are available for treatment of these inorganic and organic chemicals, but they are extremely costly. So, it is high time to consider and focus on the most important green movement three R's; Reduce, Reuse and Recycle to protect the water resources by using the process of "Phytoremediation". Aquatic plants play an important role in recycling and absorbing nutrients and heavy metals from aquatic ecosystem (Pip and Stepaniuk, 1992; Boyd, 1970; Brix and Schierup, 1989; Rao, 1986; Noemi et al., 2004). Several aquatic plants like Eichhornia crassipes, Pista stratiotes, Lemna minor exhibits an impressive level of phytoremediation of nutrient rich waste water (Manjunath and Kousar, 2016; Reed et al., 1995) and seaweeds like Sargassum sp. and Kappaphycus alvarezii have the capacity to remediate heavy metals (Bina et al., 2006; Costa et al., 1996; Holan and Volesky, 1994; Davis et al., 2000; Kang et al., 2011; Pandya et al., 2017; Rafiq et al., 2013). This work is aimed to determine suitable solution to bridge the gap between development and environmental sustainability by treating hazardous waste at the source by a cost effective method of bioremediation using aquatic plants like $E$. crassipes, $P$. stratiotes and mangrove such as Rhizophora mucronata and Bruguiera gymnorrhiza and seaweed like Sargassum wightti and $K$. alvarezii. Implementation of this method by industries will help them to work together on a single platform towards environmental protection from pollution.

\section{Material and methods}

For the present investigation, water samples were collected from the outfall area (latitude $9^{\circ} 59^{\prime} 12.56^{\prime \prime} \mathrm{N}$ and longitude $76^{\circ} 16^{\prime}$ 20. 74" E) located close to the Cochin inshore waters. Colour of water in the area was noticed to change from fluorescent blue to navy blue (Fig.1 \& Plate 1). Sampling was done twice, in the month of December, 2018 and January, 2019. Effluent water was collected from the discharge point and analysed for its odour, colour, heavy metals like copper, zinc, cadmium and lead, Dissolved Oxygen (DO), Biological Oxygen Demand (BOD), Total Suspended Solid (TSS), nutrients like nitrate, nitrite, phosphate and silicate. The main aim of this study is to bring forth a new

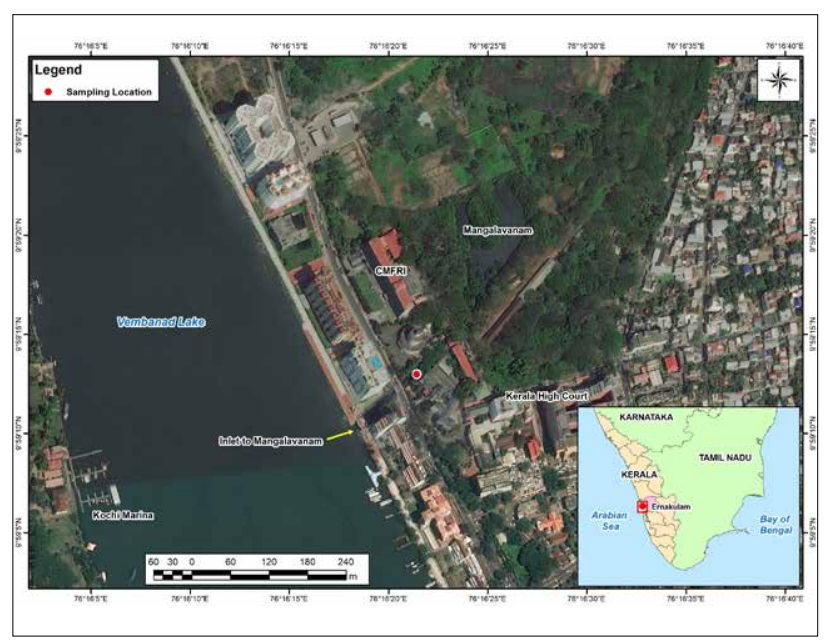

Fig. 1. GPS location of the site 

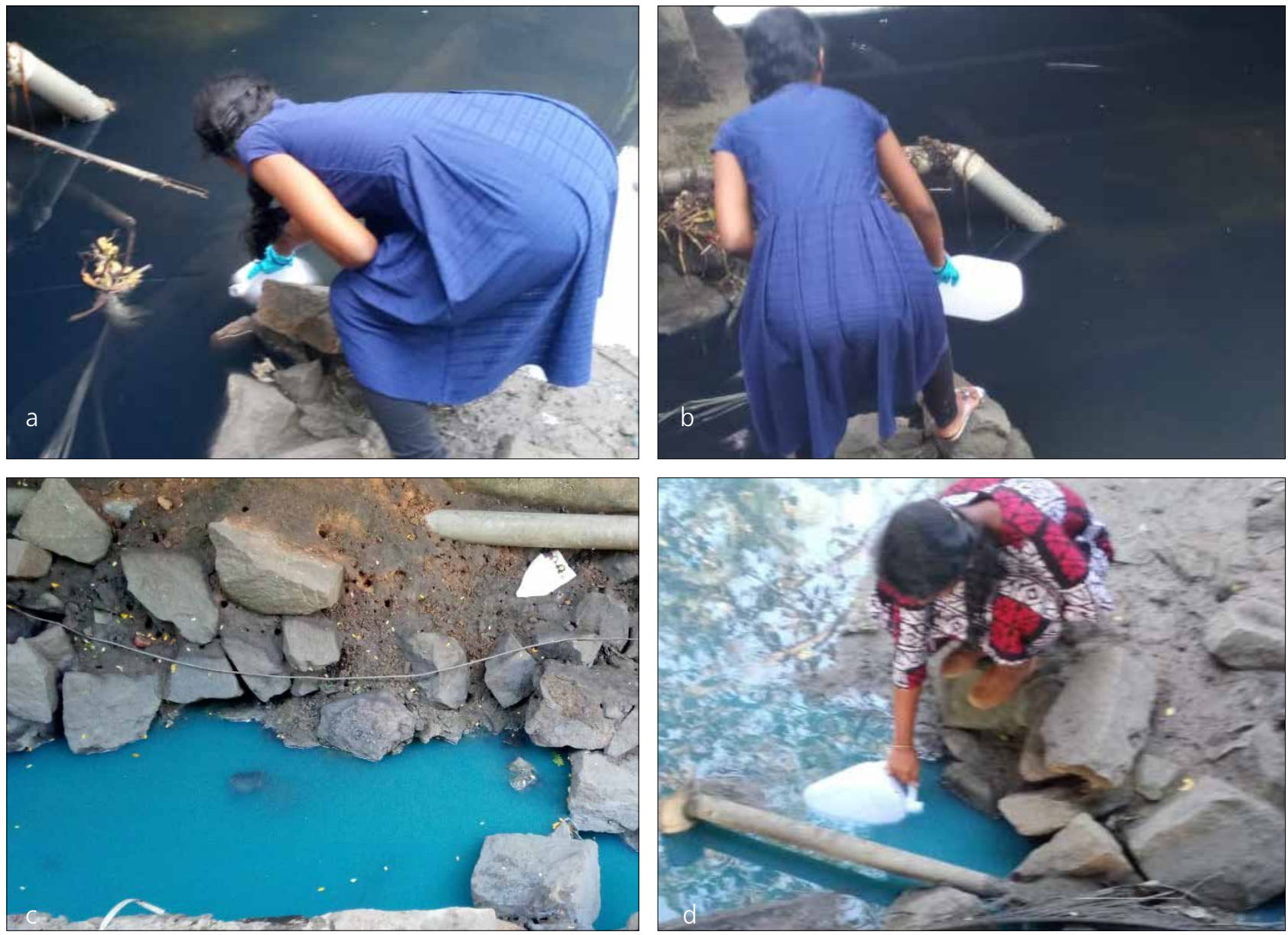

Plate 1. Effluent collected from the outfall area during sampling period 2018 (a \& b) and 2019 (c \& d).

concept of eco-friendly processes to counter contamination of water bodies by phytoremediation using various aquatic plants like E. crassipes, P. stratiotes collected from Cochin backwaters. Healthy plants were selected and washed in tap water and distilled water to remove all the organisms and particles adhering to the plant before they were used for the experiment. The mangrove saplings of $R$. mucronata and B. gymnorrhiza were collected from Mangalavanam bird sanctuary (latitude $9^{\circ} 59^{\prime} 17.74^{\prime \prime} \mathrm{N}$ and longitude $76^{\circ} 16^{\prime} 22.0^{\prime \prime} \mathrm{E}$ ). Saplings of each species were collected and transported to the laboratory in sampling zip lock cover. In the laboratory they were washed thoroughly in tap water followed by distilled water before using them for treatment of the effluent water. S. wightti was collected from the intertidal area of Alappuzha $\left(9^{\circ} 31^{\prime} 10.5^{\prime \prime} \mathrm{N}, 76^{\circ} 18^{\prime} 42.7^{\prime \prime} \mathrm{E}\right)$ and $K$. alvarezii from Mandapam coast. Algal samples were rinsed thoroughly with seawater on-site and placed in plastic bag, transferred to the laboratory. The sample was washed using freshwater to remove the salt content, any mineral particles and organisms adhering to the plant tissue followed by double distilled water without soaking for a long period and dried in a preheated oven at $75^{\circ} \mathrm{C}$ in the case of $S$. wightti and $90^{\circ} \mathrm{C}$ for $K$. alvarezii. The dried seaweeds were ground using mortar and pestle to a fine powder to be used as packs with glass beads in glass column.

Experiment was conducted in the laboratory with effluent water collected from the discharge point. They were subject to different treatments like T1, T2, T3, T4 and T5. Treatment 1 was provided only with aeration whereas treatments $\mathrm{T} 2, \mathrm{~T} 3, \mathrm{~T} 4$ and T5 were treated with different aquatic plants and mangrove seedlings like $E$. crassipes (T2), P. stratiotes (T3), R. mucronata (T4) and B. gymnorrhiza (T5) for five days (Plate. 2) along with aeration. Effluent water without aeration was maintained as Control. Water quality parameters were analyzed using standard analytical procedures like BOD, DO by Winkler (1888), ammonia by Solarzano (1969), nitrate by Grasshoff (1964), nitrite by Bendschneider and Robinson (1952), phosphate by Murphy and Riley (1962) and silicate by Mullin and Riley (1955). pH, salinity and TSS were also recorded for each sampling. Effluent was passed through a glass column to remove the excess heavy metals from the effluent water by using dried seaweed powder mixed with glass beads (Plate. 3). Two different seaweeds such as $S$. wightiiand $K$. alvarezii were used in the column separately with a constant flow rate. The elute, effluent and the seaweed 

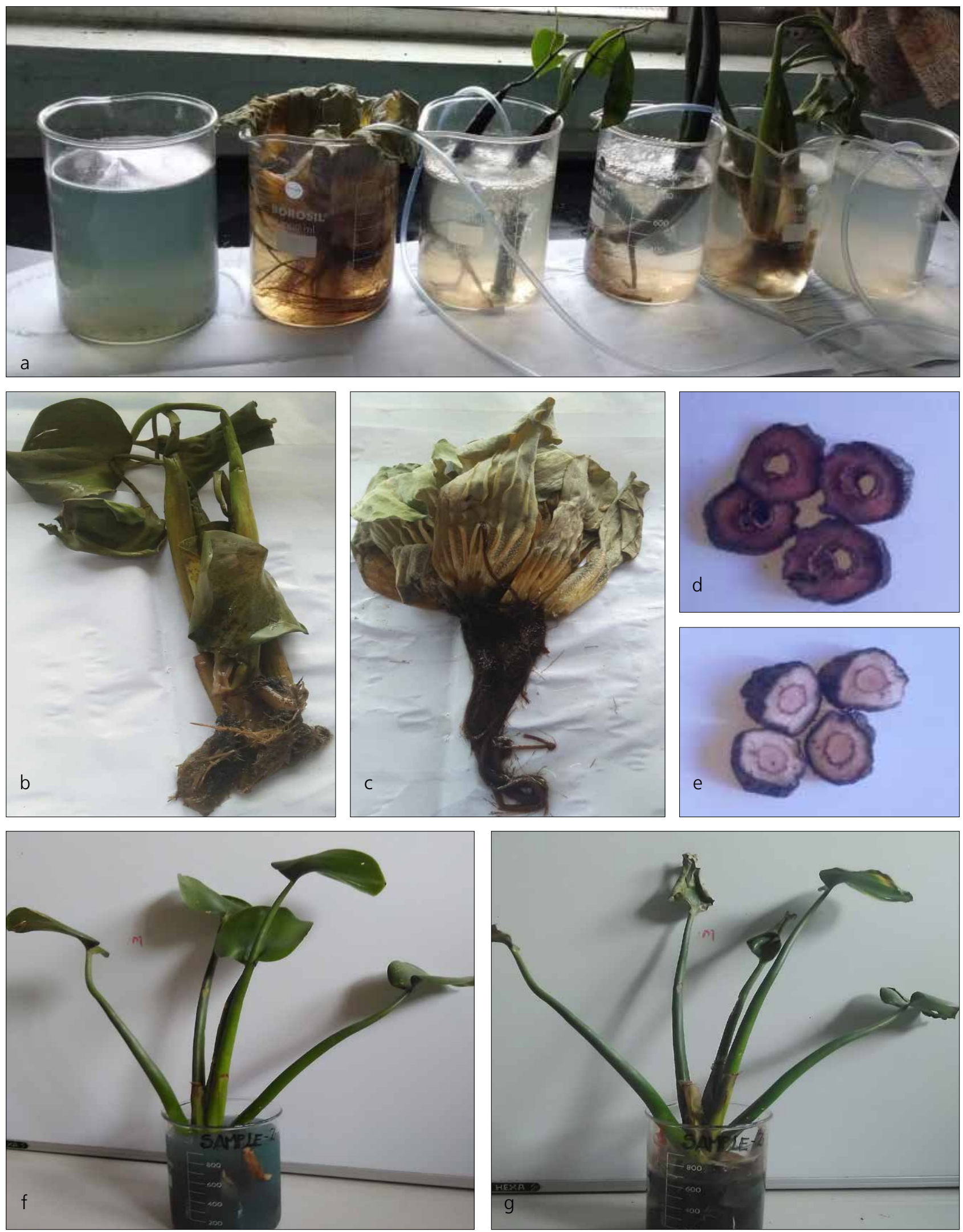

Plate 2. Experimental design of effluent treatment \& ammonia toxicity on plants after 5 days of treatment a) Experiment I b) Eichhornia crassipes c) Pistia stratiotes d) Bruguiera gymnorrhiza before e) after experiment f) Experiment II Eichornia before g) after experiment. 
sample were taken for estimation of heavy metals by using an ICP analyzer (APHA, 2017) by standard test method. All the analysis was done in triplicate. The data generated from the experiment were analyzed statistically by multivariate bootstrap Hotelling's T square tests.

\section{Results}

Analysis of physicochemical parameters of normal estuarine water (ESW), effluent water (EFW) and the treated effluent water (TEFW) were carried out and are presented in this paper. Physical observations at the time of collection showed tiny white suspended particles and colour of the water was blue to fluorescent blue. The effluent had very pungent odour from the chemicals. Salinity of the EFW sample ranged between 6-15 ppt compared to the ESW which was always 19 ppt and above. TSS value of the EFW was $124.0 \mathrm{mg} / \mathrm{l}$ compared to ESW with $86 \mathrm{mg} / \mathrm{l}$. pH of the EFW was found to be slightly alkaline in nature (8.1) compared to ESW which was 7.9 (Fig. 2).

Upon treatment for 5 days, the TSS value declined from 124 to $60 \mathrm{mg} / \mathrm{lin} \mathrm{T} 4$ by using mangrove $R$. mucronata and to $65.0 \mathrm{mg} / \mathrm{l}$ in T3 when treated with $P$. stratiotes, almost the same value of estuarine water. The $\mathrm{pH}$ of EFW did not show much variation than ESW before or after treatment with aquatic plants. There

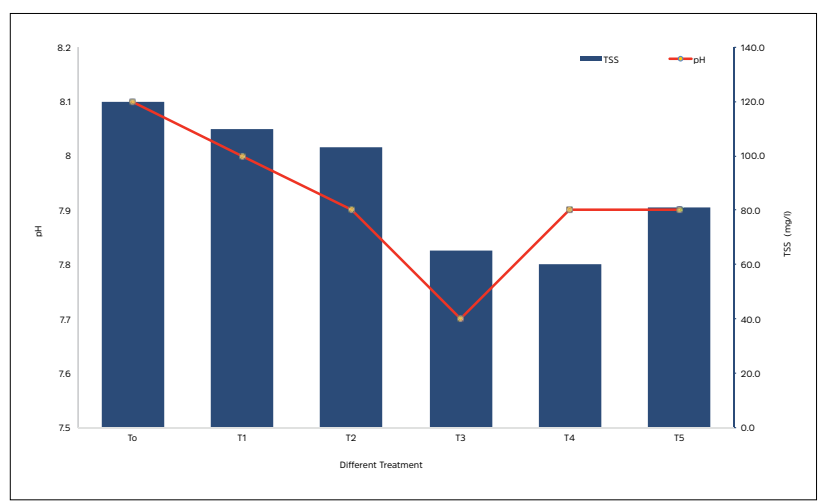

Fig. 2. TSS, Salinity and pH in effluent and normal estuarine water

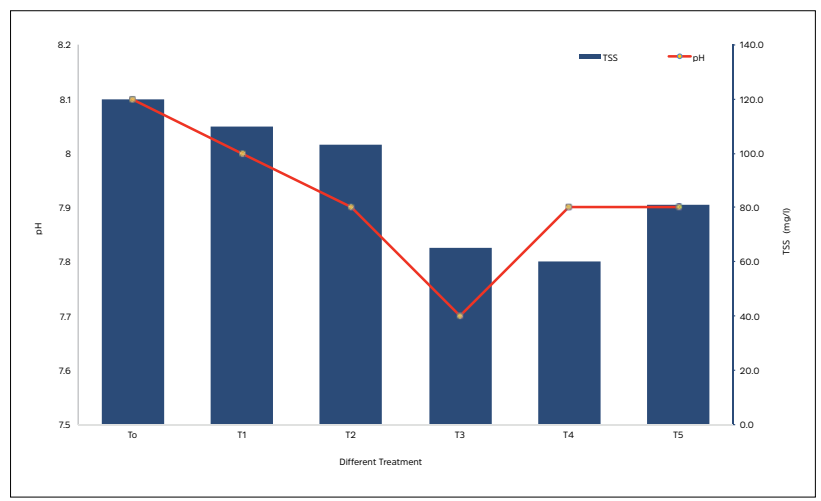

Fig. 3. TSS and pH effluent after 5 days of different treatment

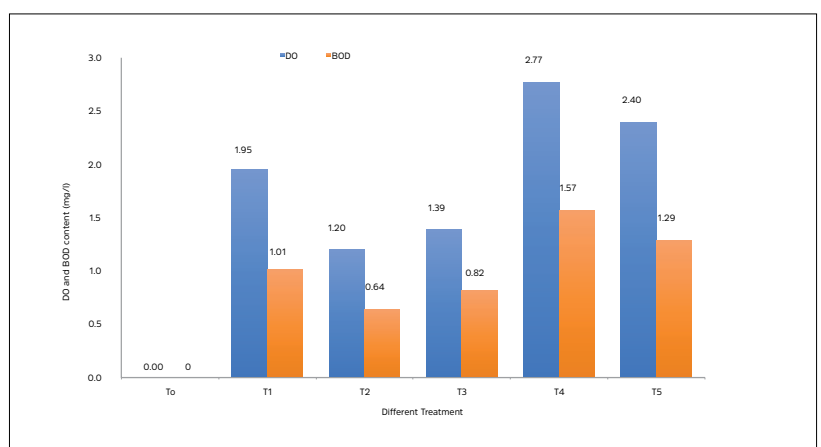

Fig. 4. DO and BOD value of effluent under different treatment

was marginal decline of $\mathrm{pH}$ by $5 \%$ from 8.1 to 7.7 when treated with aquatic weed $P$. stratiotes (Fig. 3). The second collection of effluent from the same outfall area showed very high value of TSS $(419.6 \mathrm{mg} / \mathrm{l})$ which significantly declined to $68 \mathrm{mg} / \mathrm{l}$ when treated with $E$. crassipes in T2. Highly significant variation was observed in the TSS of effluent sample under different treatment $(p<0.05)$.

DO and BOD value was found to be zero just after collection. The DO as well as BOD values increased to $1.2-2.7 \%$ after the treatment, where the maximum increase was exhibited when treated with mangroves. The DO value increased from 0 to $2.77 \mathrm{mg} / \mathrm{l}$ when treated with $R$. mucronata (T4) whereas it was $2.4 \mathrm{mg} / \mathrm{lin}$ B. gymnorrhiza (T5). Similarly, the BOD value also showed an increase in a similar way with $1.57 \mathrm{mg} / \mathrm{l}$ in $\mathrm{T} 4$ and $1.29 \mathrm{mg} / \mathrm{lin}$ T5. The effluent treated with aeration also had a DO value of $1.95 \mathrm{mg} / \mathrm{l}$ and BOD value of $1.01 \mathrm{mg} / \mathrm{l}$ whereas in controlled condition both the values remained zero even after 5 days (Fig.4). During the second collection of effluent, DO and BOD showed significant increase from zero to 2.38 and $1.44 \mathrm{mg} / \mathrm{l}$ respectively when treated with $E$. crassipes (T2). There was a highly significant variation in BOD value of effluent sample $(p<0.05)$ but DO did not show any statistical significance.

Ammonia content of the effluent water was higher compared to nitrate and nitrite. While comparing with different treatments ammonia reduced marginally ranging from 4.0 to $10.5 \%$. Maximum decline was found in $R$. mucronata and B. gymnorrhiza from an initial value of 4.05 to $3.62 \mathrm{mg} / \mathrm{l}$ and $3.63 \mathrm{mg} / \mathrm{l}$ respectively (Fig.5). The ammonia content in ESW $(0.14 \mathrm{mg} / \mathrm{l})$ was very low compared to the EFW $(4.05 \mathrm{mg} / \mathrm{l})$. Highly significant variation was observed in the ammonia content of effluent sample under different treatment $(p<0.05)$.

Nitrite and nitrate content of the effluent water were 0.038 and $0.049 \mathrm{mg} / \mathrm{l}$ compared to the normal estuarine water with a value of 0.026 and $0.045 \mathrm{mg} / \mathrm{l}$. Nitrite content under different treatment ranged between 7.89 and $44.5 \%$ and was effectively removed in $P$. stratiotes $(0.021 \mathrm{mg} / \mathrm{l})$ followed by $E$. crassipes $(0.024 \mathrm{mg} / \mathrm{l})$. The mangrove plants also exhibited 

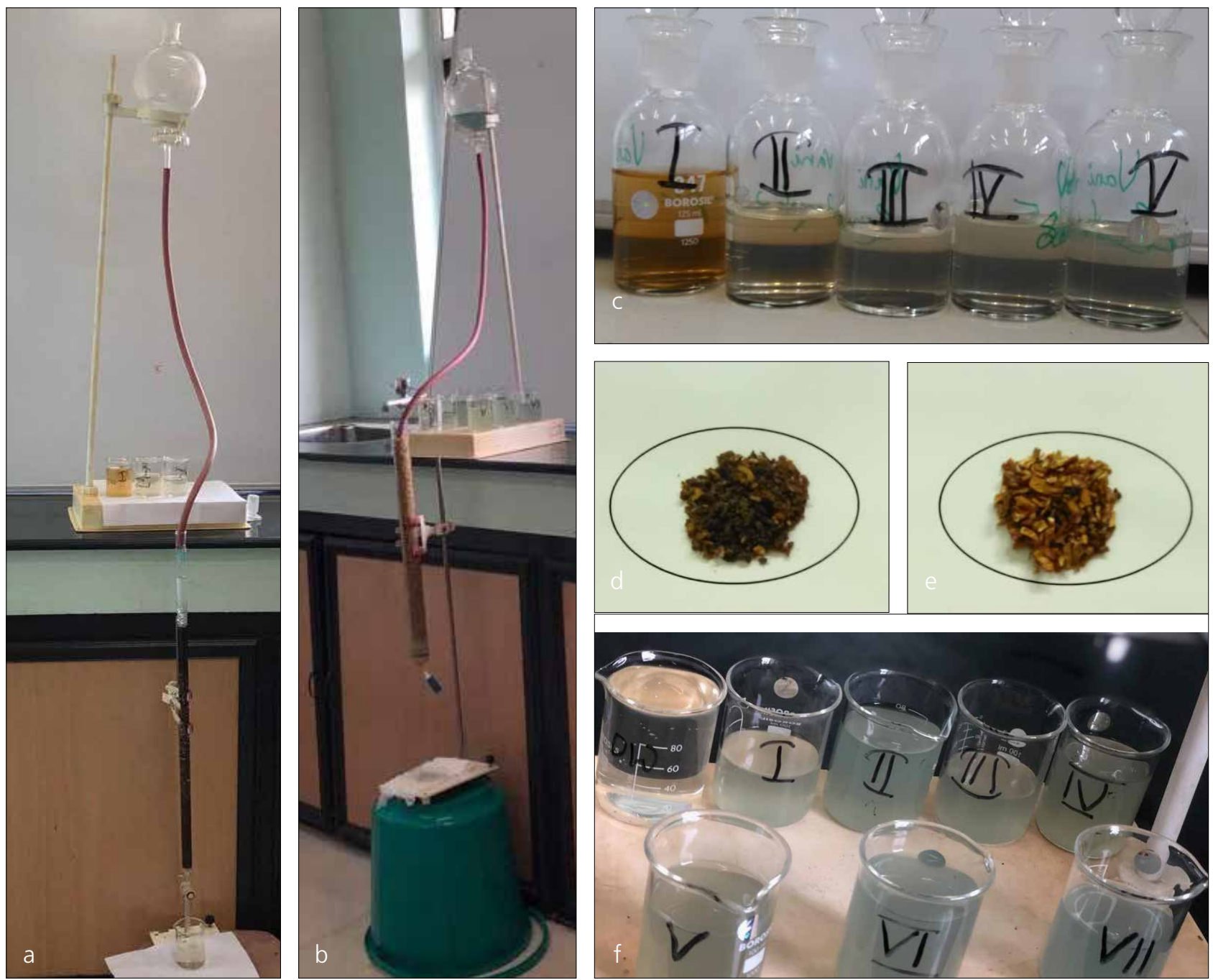

Plate 3. Effluent passed through seaweed granules a) Sargassum granules b) Kappaphycus granules c) Elute collected after the effluent passed through column of Sargassum wightti d \& e) colour of Kappaphycus granunles before and after effluent pass through glass column f) Elute collected after the effluent passed through column of Kappaphycus alvarezii.

decline in the nitrite content to $0.031 \mathrm{mg} / \mathrm{l}$ (T5) and 0.033 $\mathrm{mg} / \mathrm{l}$ (T4). Nitrate content was not as high in the effluent water sample compared to the ESW. Decrease in nitrate to $0.037 \mathrm{mg} / \mathrm{l}$ was noticed effectively by $E$ crassipes and $B$ gymnorrhiza $(0.037 \mathrm{mg} / \mathrm{l})$. Nitrate and nitrite content did not show any statistical significance.

Phosphate content declined significantly from $2-90.5 \%$ with different treatments and the maximal reduction was observed in $R$. mucronata (T4) with a value of $0.033 \mathrm{mg} / \mathrm{l}$ from 0.346 $\mathrm{mg} / \mathrm{l}$ followed by $B$. gymnorrhiza $(0.053 \mathrm{mg} / \mathrm{l})$ and $P$. stratiotes $(0.063 \mathrm{mg} / \mathrm{l})$. The phosphate content of ESW was $0.054 \mathrm{mg} / \mathrm{l}$. Silicate content in the ESW was $0.371 \mathrm{mg} / \mathrm{l}$. Silicate present in the effluent water was found to be higher similar to ammonia and phosphate with a value of $2.990 \mathrm{mg} / \mathrm{l}$. Silicate content declined from 4 to $63.9 \%$ under different treatment and the diminishing value of silicate was found higher in $E$ crassipes
$(1.07 \mathrm{mg} / \mathrm{l})$ followed by $R$. mucronata with a value $1.78 \mathrm{mg} / \mathrm{l}$ (Fig. 6). Highly significant variation was observed in the phosphate and silicate content of effluent sample under different treatment $(p<0.05)$.

The effluent sample was passed through the column packed with seaweed powder of $S$. wightii. The transmittance of the eluted water showed the colour change from blue to light blue (Plate. 3). Analysis of heavy metals, showed presence of zinc and copper and the absence of cadmium and lead in the effluent water. The amount of zinc present in the EFW sample was higher $(0.71 \mathrm{mg} / \mathrm{l})$ compared to copper $(0.16$ $\mathrm{mg} / \mathrm{l})$ whereas the elute did not show any detectable levels of copper and zinc. Prior to treatment the seaweed powder which lacked heavy metals like zinc and copper showed accumulation of zinc $(17.60 \mathrm{mg} / \mathrm{kg})$ and copper $(1.96 \mathrm{mg} /$ $\mathrm{kg}$ ) after the treatment. The effluent collected from the same 


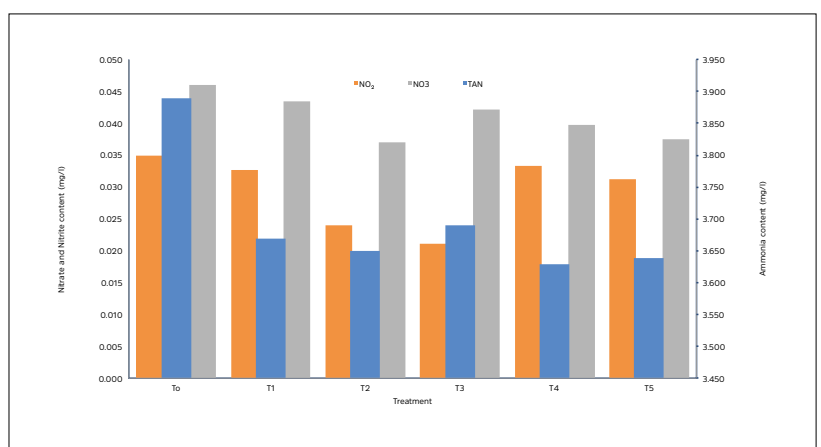

Fig. 5. Ammonia, Nitrite and Nitrate content of effluent under different treatment

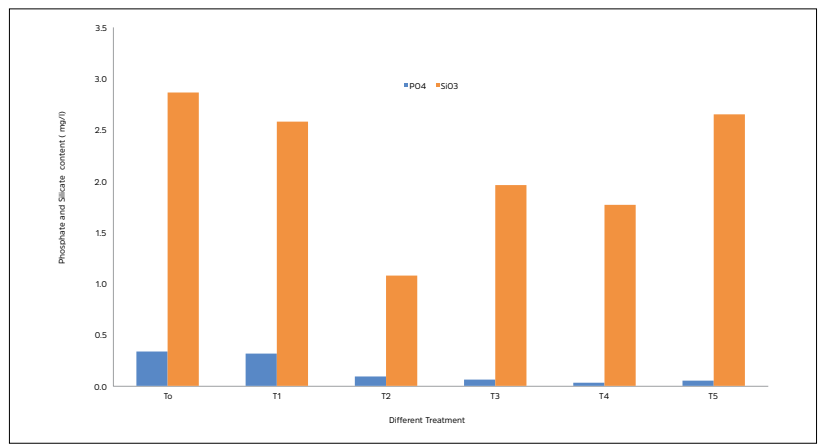

Fig. 6. Phosphate and silicate content of effluent under different treatment

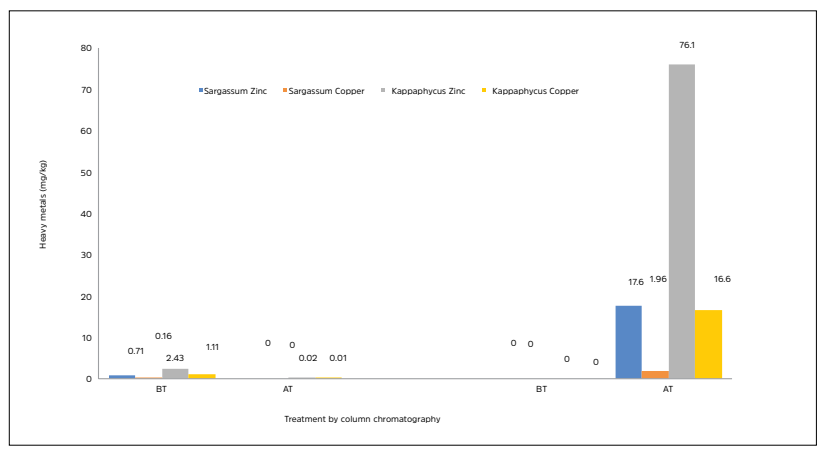

Fig. 7. Biosorption of heavy metals by seaweeds

outfall area for the second time was also passed through the column packed with seaweed granules of $K$. alvarezii. The amount of zinc present in the EFW sample was higher ( 2.43 $\mathrm{mg} / \mathrm{l})$ compared to copper $(1.11 \mathrm{mg} / \mathrm{l})$. The amount of zinc present in the effluent reduced to $0.02 \mathrm{mg} / \mathrm{l}$ and copper to $0.01 \mathrm{mg} / \mathrm{l}$ after the treatment (Fig. 6). The elute did not show much variation in the color rather was converted to pale ash color due to the pigment present in the dried seaweed powder of $K$. alvarezii. Thus, transmittance of the elute treated with K. alvarezii was $25.11 \%$ compared to $63.39 \%$ in effluent sample. Seaweed samples in the column was dried in a preheated oven which showed almost a dark brown color compared to pale yellow in the untreated sample (Plate. 3). Initially the seaweed powder which did not contain any zinc or copper could accumulate $76.1 \mathrm{mg} / \mathrm{kg}$ zinc and 16.6 $\mathrm{mg} / \mathrm{kg}$ of copper respectively after the treatment (Fig. 7).

\section{Discussion}

The salinity of effluent water was less compared to the normal estuarine water which may be due to the frequent release of fresh effluent from the nearby industry getting mixed with the canal water, where the salinity is influenced by the tide. There is not much variation in the $\mathrm{pH}$ of effluent water and normal estuarine water, which may be due to chemical pollution rather than organic pollution. It can also be emphasized that no strong acid or alkaline chemicals were released with the effluent. Dissolved oxygen is the major factor in determining water quality. DO exhibited the clear-cut evidence of chemical pollution in water bodies which did not allow any plants and bacteria to grow in the outfall area and making the area a dead zone. Low oxygen concentrations are generally associated with heavy contamination by organic matter (Madhusudhanan and Jayesh, 2011). But here the area was not contaminated with organic pollutant as evidenced by the zero level of BOD during collection. After the effluent was exposed to aeration and treatment, there was very negligible recovery of the effluent with a minimal value of DO and BOD allowing the bacteria to grow in the system and thus helping in nitrogen cycle.

Ammonia is used either directly or indirectly in industries and agriculture and if discharged to natural water sources without treatment, are hazardous (Sheela and Beebi, 2014). There are different methods to treat effluents like adsorption, chemical precipitation, advanced oxidation processes (AOPs) such as direct photo oxidation (Wang et al., 1994). These methods have disadvantages because of continuous input of expensive chemical which is not very cost effective whereas the process of bioremediation is simple, eco-friendly, cost effective and can be used in any aquatic environment for removal of excessive ammonia or heavy metals present in the industrial effluent. In the present experiment, the effluent discharged without proper treatment from nearby industries to natural water had strong pungent smell of ammonia. In the presence of high level of ammonia and zero oxygen, nitrogen assimilation was negligible thereby showing very low concentrations of nitrate and nitrite in effluent water. Thus, the nitrogen cycle of the effluent was not taking place in the strong anaerobic condition, to convert the ammoniacal nitrogen to nitrite and nitrate and made available to the plants. Report states that during such condition the aerobic bacteria will be washed off from the effluent and ammonium would be converted to mainly nitric oxide and nitrous oxide (Sliekers et al., 2005; Keluskar et al., 2013). Rittmann and Mc Carty (2001) stated that the most common genus of bacteria that carries out ammonia oxidation is Nitrosomonas species (beta 
subdivision of proteobacteria) whereas conversion of nitrite to nitrate by alpha subdivision of proteobacteria, Nitrobacter.

Even though plants have the potential to absorb the required nutrients for their growth and development, they are unable to absorb these nutrients due to very high dose of ammoniacal nitrogen which affect the root and shoot system of aquatic plants showing symptom of wilting. Similar damage was also observed in the cortical layer of the mangrove plant (Plate 2). Reduction of ammonia from the effluent water after treatment was quite low which is contrary to the work of Sooknah and Wilkie (2004) where the reduction in ammoniacal nitrogen was more than $99 \%$ when aquatic macrophyte were cultured in anaerobically digested flushed dairy manure wastewater. When pollution is caused due to heavy metals and inorganic ammonical nitrogen, it completely damages the system making it a dead zone. Such condition can gradually affect the nearby mangrove ecosystem. Untreated wastes when channelled into aquatic environment causes extensive damage to water quality and ecology of the environment specifically when microbial degradation activities cannot cope up with the fast removal of the toxic pollutants (Obire et al., 2008).

Effluent treated with mangrove plant exhibited decline in the value of nitrogen and phosphorus content which may be due to efficient uptake of nutrients by mangroves for their metabolic activities. Lack of DO and BOD with a higher value of $96 \%$ ammonia, $84.3 \%$ phosphate and $87.6 \%$ silicate content observed in the effluent with reference to the normal estuarine water show the gravity of the situation and its impact on the aquatic flora and fauna. Deshmukh et al. (2011) observed $69.9 \%$ phosphate removal by Eichhornia sp which is similar to the present experiment $(71.9 \%)$ and $47.27 \%$ by Pistia sp which is almost half to that reported in this study (81.8\%).

Heavy metals like copper and zinc was also detected in the effluent. S. wightii could accumulate zinc ( $17.6 \mathrm{mg} / \mathrm{kg})$ and copper $1.96(\mathrm{mg} / \mathrm{kg})$ whereas $K$. alvarezii could accumulate $76.06(\mathrm{mg} /$ $\mathrm{kg}$ ) of zinc and $16.64(\mathrm{mg} / \mathrm{kg})$ of copper from the effluent. Lead and cadmium were within permissible limit. Earlier reports also explained that $K$. alvarezii is a good bio sorbent for the removal of nutrients (Rathod et al., 2014) and heavy metals (Kang et al., 2011) from the aquatic environment. The bio adsorption efficacy of heavy metals was found to be better in $K$. alvarezii than $S$. wightii because of the high phycocolloid (carrageenan) present in the plant than the algin content in $S$. wightii. The bio adsorption efficacy can further be improved in $K$. alvarezii by reducing the particle size of the plant used for experiment.

Bioremediation is a suitable solution and cost effective method for treating hazardous waste at the discharge point. It is suggested that industries adopt this cost effective technology of effluent treatment so as to reap benefit from the approach. This can lead to the reuse of an important resource like freshwater and also mining the heavy metals can be accomplished through phytomining. Simultaneously, it will safeguard natural water bodies from pollution and maintain synergy with the aquatic flora and fauna.

\section{Acknowledgements}

The first author sincerely thanks the Director, ICAR-Central Marine Fisheries Research Institute (CMFRI), Cochin for permitting to work in the Institute for her M.Sc. dissertation work. Sincere thanks to Dr. Reeta Jayasankar, Principal scientist, ICAR-CMFRI for guiding and the Kerala University of Fisheries and Ocean Studies (KUFOS), Panangad for providing permission to conduct dissertation work in ICAR-CMFRI.

\section{References}

Anjusha, K. V., A. M. James, F. A Thankachan, J. Benny and V. B. Hezakiel. 2020. Assessment of Water Pollution Using GIS: A Case Study in Periyar River at Eloor Region. In: H. Drück, J. Mathur, V. Panthalookaran and V. M. Sreekumar (Eds.) Proceedings of International Symposium on the Green Buildings and Sustainable Engineering, Springer, Singapore, 189721. p. 413-420.

APHA, 2017. Standard Methods for the Examination of Water and Wastewater. 23rd Edition, American Public Health Association/ American Water Works Association/ Water Environment Federation, Washington DC: 1 v. [various pagings]

Bendschneider, K. and R. J. Robinson. 1952. A new spectrophotometric method for the determination of nitrite in sea water. Technical Report, 8. University of Washington, Seattle and Friday Harbor, Washington. p. 1-3.

Bennett, L. E., J. L. Burkhead, K. L. Hale, N. Terry, M. Pilon and E. A. Pilon-Smits. 2003. Analysis of transgenic Indian Mustard plants for phytoremediation of metalscontaminated mine tailings. J. Environ. Qual., 32: 432-440.

Bina, B., M. Kermani, H. Movahedian and Z. Khazaei. 2006. Biosorption and Recovery of Copper and Zinc from Aqueous Solutions by Non-living Biomass of Marine Brown Algae of Sargassum sp. Pakistan J. Biol. Sci., 9(8): 1525-1530.

Boyd, C. E. 1970. Production, mineral nutrient accumulation and pigment concentration in Typha latifolia and Scripus americaus. Ecology, 51: 285-290.

Brix, H. and H. H. Schierup. 1989. The use of aquatic macrophytes in water pollution control. Ambiol., 18: 100-107.

Da Costa, A. C. A. and F. P. de Franca. 1996. Biosorption of zinc, cadmium, and copper by a brown seaweed (Sargassum sp.) in a continuous fixed-bed laboratory reactor. Bioseparation, 6(6): 335-341.

Davis, T. A., B. Volesky and R. H. S. F. Vieira. 2000. Sargassum seaweed as biosorbent for heavy metals. Water Res., 34(17): 4270-4278.

Deshmukh, A. A., N. N. Bandela, J. R. Chavan and P. M. Nalawade. 2013. Studies on potential use of water hyacinth, Pistia and Azolla for municipal wastewater treatment. Indian J. Appl. Res., 3(11): 226-228.

Grassoff, K. 1964. Zur Bestimmung von Nitrat in Meer-und Trinkwasser. Kiel. Meeresforsch., 20(1): 5- 11.

Holan, Z. R. and B. Volesky. 1994. Biosorption of lead and nickel by biomass of marine algae. Biotechnol. Bioeng., 43(11): 1001-1009.

Ikhuoria, E. U. and F. E. Okieimen. 2000. Scavenging cadmium, copper, lead, nickel and zinc ions from aqueous solution by modified cellulosic sorbent. Int. J. Environ. Stud., 57(4): 401-409.

Kang, O. L., N. Ramli, M. Said, M. Ahmad, S. M. Yasir and A. Ariff. 2011. Kappaphycus alvarezii waste biomass: a potential biosorbent for chromium ions removal. J. Environ. Sci., 23(6): 918- 922.

Keluskar, R., A. Nerurkar and A. Desai. 2013. Development of a simultaneous partial nitrification, anaerobic ammonia oxidation and denitrification (SNAD) bench scale process for removal of ammonia from effluent of a fertilizer industry. Bioresour. Technol., 130: 390- 397.

Madhusudhanan, K. and R. Jayesh. 2011. Physico-chemical and floristic studies of Mangalavanam mangrove ecosystem in Ernakulam District, Kerala, South India. Nat. Environ. Pollut., 10(1): 15-20.

Manjunath, S. and H. Kousar. (2016). Phytoremediation of Textile Industry Effluent using Pistia stratiotes. Int. J. Environ. Sci., 5(2):55-81. 
Moezzi, A., A. M. McDonagh and M. B. Cortie. 2012. Zinc oxide particles: Synthesis, properties and applications. Chem. Eng. J., 185:1-22.

Mullin, J. and J. P. Riley. 1955. The colorimetric determination of silicate with special reference to sea and natural waters. Analytica Chimica Acta, 12: 162-176.

Murphy, J. and J. P. Riley. 1962. A modified single solution method for the determination of phosphate in natural water. Analytica Chimica Acta, 27: 31- 36.

Noemi, R., A. Moshe and O. Gideon. 2004. A pilot study of constructed wetlands using duckweed (Lemna gibba L.) for treatment of domestic primary effluent in Israel. Water Res., 38: 2241-2248.

Obire, O., A. Ogan and R. N. Okigbo. 2008. Impact of fertilizer plant effluent on water quality. Int. J. Environ. Sci. Technol., 5: 107- 118.

Pandya, K. Y., R. V. Patel, R. T. Jasrai and N. Brahmbhatt. 2017. Preliminary study on potential of seaweeds in decolorization efficacy of synthetic dyes effluent. Int. J. Plant, Animal and Environ. Sci., 7(1): 59-69.

Pip, E. and J. Stepaniuk. 1992. Cadmium, copper and lead in sediments and aquatic macrophytes in the Lower Nelson River system, Manitoba, Canada. I: Interspecific differences and macrophyte-sediment relations. Arch. Hydrobiol., 124(3): 337-355.

Rathod, M., K. Mody and S. Basha. 2014. Efficient removal of phosphate from aqueous solutions by red seaweed, Kappaphycus alvarezii. J. Clean. Prod., 84: 484- 493.

Rafiq, S., M. K. Ali, M. Sakari, J. Sulaiman and S. M. Yasir. 2013. Biosorption of toxic heavy metals by unmodified marine red alga (Kappaphycus alvarezii): Kinetics and isotherm studies. Int. J. Environ. Bioener., 7(2): 91-107.

Rao, S. V. R. 1986. A review of the technological feasibility of aquaculture for municipal wastewater treatment. Int. J. Environ. Stud., 34: 219-223.
Reed, S. C., R. W. Crites and E. J. Middlebrooks. 1995. Natural systems for waste management and treatment, 2nd ed, McGraw-Hill Inc., New York. 433pp.

Rittmann, B. E. and P. L. Mc Carty. 2001. Environmental biotechnology. Principles and applications. Mc Graw-Hill Education, New York, 768 pp.

Sheela, B. and K. Beebi. 2014. Bioremediation of ammonia from polluted waste waters. Am. J. Microbiol. Res., 2(6): 201- 210.

Sliekers, A. O., S. C. Haaijer, M. H. Stafsnes, J. G. Kuenen and M. S. Jetten. 2005 Competition and coexistence of aerobic ammonium- and nitrite-oxidizing bacteria at low oxygen concentrations. Appl. Microbiol. Biotechnol., 68(6): 808-817.

Sobha, V. and M. Anish. 2003. Imprints of environmental pollution on laterite / clay and ground water of Eloor-Kalamassery Industrial Belt, Kerala state, India. Environ. Geol., 44(8): 914-918.

Solarzano, L. 1969. Determination of ammonia in natural waters by the phenolhypochlorite method. Limnol Ocenogr., 14(5): 799- 801.

Sooknah, R. D. and A. C. Wilkie. 2004. Nutrient removal by floating aquatic macrophytes cultured in anaerobically digested flushed diary manure wastewater. Ecol. Eng., 22: 27- 42.

Sumangala, K. N., P. S. Akhil and C. H. Sujatha. 2013. Hydrogeochemical quality assessment of ground waters in Ernakulam District, Kerala, India. J. Environ. Sci. Comput. Sci. Eng. Tech., 2(4):1353-1368.

Wang, A., J. G. Edwards and J. A. Davies. 1994. Photo oxidation of aqueous ammonia with titania-based heterogeneous catalysts. Sol. Energy, 52: 459- 466.

Winkler, L. W. 1888. The determination of dissolved oxygen in water. Ber. Dtsch. Chem. Ges., 21: 2843- 2855. 